\title{
Concept of Sea Power
}

\author{
Torsten Albrecht, Konstantinos Tsetsos, and Philipp Grunwald
}

\section{Contents}

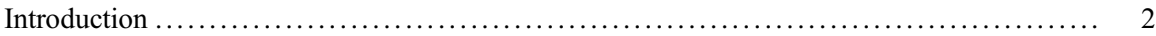

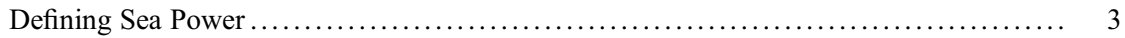

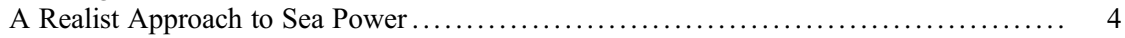

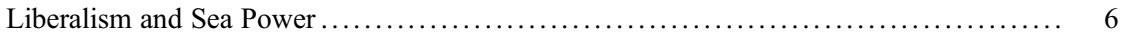

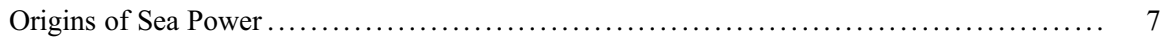

Mahan's Principles of Sea Power ......................................... 7

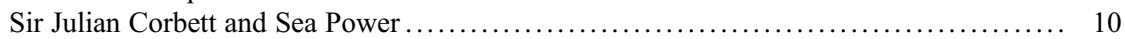

Changes After the Second World War ...................................... 12

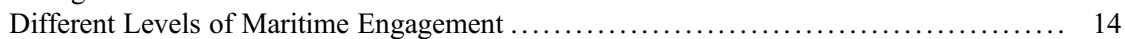

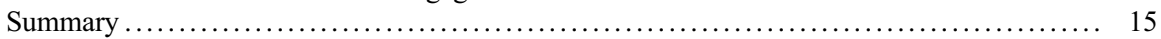

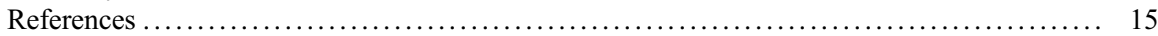

\section{Abstract}

In this chapter different perspectives on the concept of sea power are considered. On the one hand, sea power is defined accordingly, whereby it must be emphasized that sea power is not only composed of the number of ships or material but also of the degree to which it can influence and compel other countries/actors. The concept of sea power is then examined based on the International Relations theories of Realism and Liberalism. In order to understand the origins and also the development in the twentieth century of the concept of sea power, the most important cornerstones of the leading naval thinkers of the "blue-water school,"

\section{T. Albrecht}

Bundeswehr University, Hamburg, Germany

e-mail: talbrecht@uni-potsdam.de

K. Tsetsos $(\square)$

Political Science Institute, Bundeswehr University Munich, Neubiberg, Germany

e-mail: k.tsetsos@unibw.de

P. Grunwald

Bundeswehr University Munich, Neubiberg, Germany

e-mail: philipp.grunwald@sicyon.de 
Alfred Thayer Mahan and Sir Julian Corbett, are presented. This work ends with a review of the concept of sea power during the Cold War.

\section{Keywords}

Sea power - Naval power - Realism - Liberalism · Mahan · Corbett · Cold War · Maritime environment $\cdot$ Blue-water school

\section{Introduction}

The importance of sea power, while appreciating other influences such as air power, is beyond doubt. Anyone approaching the subject of sea power from a historical perspective is reminded by a number of historical examples of the consequences of (non-)control of the seas. For example, the Phoenicians controlled the Mediterranean and were thus able to expand their trade, and the Ottomans were defeated at Lepanto, which led to the final collapse of their land forces. Continuing the view through history, for example with the efforts of the United States, Japan, Germany, and the Soviet Union to gain influence on the seas, one can find many more examples of the importance and relevance of sea power in the past, but also in the present (Gough 1988, p. 55). For in today's world, we must not forget that despite the many technical possibilities in all dimensions of military deployment, sea power has a fundamental value in terms of global influence. In times of globalization and, for example, the associated global trade routes, the importance of sea power, for example, monitoring these routes, is crucial. Many other facets of today's sea power applications can be enumerated, but finally, even with the technological progress of the twenty-first century, as history has shown, sea power is needed to determine the direction of continental and intercontinental development (Moore 1975, p. 15; Till 1984; Nailor and Bolton 1986). Based on the significance of sea power, it can be concluded that the consideration of the theory of sea power is important both historically and today. At the time of the late nineteenth century and early twentieth century, two classical theorists, Alfred Thayer Mahan and Sir Julian Stafford Corbett, in particular, came to prominence, who laid down the foundations and principles of maritime strategy. At these times, sea power meant the central means of controlling national activities and power projection over rivals. This categorization of sea power can no longer be matched by today's technological innovations. "But in the classical era of the battleship, these two strategists and historians of sea power labored to convince other of the value and utility of a nation-state possessing a sea-going capability that could fulfil and meet the national objectives of that nation-state in time of war" (Gough 1988, p. 55).

In the following, sea power will be defined and the changes the concept of sea power has undergone over time will also be discussed. On this basis, sea power will then be put into a theoretical context and it will be examined how Alfred Thayer Mahan and Sir Julian Stafford Corbett laid the foundations of sea power theory. This work is concluded with a consideration of the theoretical concept of sea power after the Second World War up to the present day. 
In the following section of this work a definition of sea power will be formulated. It is interesting to note that Mahan himself, who coined the term sea power, did not give a final definition. Subsequently, sea power will be examined from various International Relations theory perspectives.

\section{Defining Sea Power}

Finding an all-encompassing definition of sea power is difficult due to the following problems. Apart from semantic limitations of the English language and the question whether maritime terms do justice to all facets of sea power, the question also arises what exactly the "power" in sea power actually means. On the one hand, analysts focus on factors that make countries or people powerful (e.g., pure military strength). On the other hand, they also focus on the perspective of defining power by whether countries are able to let others do what they want. In other words, power can thus be represented in terms of potential or consequences (or both at the same time) (Till 2009, p. 20). A concept of sea power must include both views of power, the potential and the consequential view. The potential of sea power is defined by the presence and number of navies, coast guards, marine, and civil-maritime industries. The influence of these forces on land and air forces can also be mentioned here. Overall, it is therefore the civil and military potential that is defined by the number and availability of all types of personnel and material needed to use the sea (Till 2009, p. 21). However, as already indicated, sea power cannot be defined by the mere number of, for example, ships or personnel, but also by the degree of possibility to influence the behavior of other states. This refers on the one hand to the influenceable behavior at sea, but also to the influence one has on decision-making processes on land. As Sir Julian Corbett rightly said, sea power is not necessarily about what exactly happens at sea, but about the outcomes of the influence of sea power on land: "Since men live upon the land and not upon the sea, great issues between nations at war have always been decided - except in the rarest cases - either by what your army can do against your enemy's territory and national life, or else by fear of what the fleet makes it possible for your army to do" (Corbett 1918, p. 67). In other words, it is not only relevant how sea power is executed at sea, but also how power from the sea affects behavior and processes on land. As pointed out by Geoffrey Till (2009, p. 21), sea power must be defined as input, that is the sum of the various naval and maritimerelated assets, as well as output, that is, the ability to influence the behavior of other actors.

With these two sides of the definition of sea power, some derivations can be made immediately, which should be considered for the further consideration of sea power. On the one hand, it has become clear that sea power is not simply defined by the ships of a country, but also by the mutual understanding that other services have an influence on processes at sea and that the deployment of a navy also has an influence on processes on land or in the air. This is accompanied by the fact that sea power is not only to be considered through its purely military component, but that the nonmilitary aspect of the use of the sea is just as relevant for the determination of 
sea power. Merchant fleets, the fishing industry, shipbuilding and maintenance, maritime research, or even the insurance business all have an influence on naval power and thus also influence in their own way the possibilities of influencing other states. On the other hand, it can also be deduced that sea power is a relative concept. In other words, some states have more sea power than others, and the question is only about the degree of difference, because almost all countries have some sea power, either based on the strength of the military or through, for example, shipbuilding skills or corresponding insurance companies in the sector. The decisive factor here is that sea power of one state can be significantly higher than that of other states. This difference has a significant impact on the strategic planning of states in peace as well as in war (Till 2009, p. 22).

The aspect of relativity is a meaningful derivation, since it allows us to approach questions of whether and to what extent a country can demonstrate sea power. However, it should be noted that this comprehensive definition of sea power means that virtually every state in the world has a certain degree of sea power. This also means that the size of the available sea power is not necessarily decisive for being able to operate at sea. If, for example, typical mechanisms are in place during a warlike conflict (e.g., attacks on ships or pursuit of battles), one can speak of the use of sea power. This can be applied in almost all states, regardless of size or form (Sater 1991). The relativity mentioned above also means that the effectiveness of sea power depends heavily on the strengths and weaknesses of the opponent. Sea power can have different effects in conflicts. In some circumstances, the use of sea power merely creates the possibility of winning the conflict on land or in the air; in other scenarios, sea power is the decisive factor for ending a conflict (Gray 1999, p. 217).

\section{A Realist Approach to Sea Power}

From a Realist perspective, states are viewed as uniform actors or units. These units possess national interests and seek to selfishly assert themselves within a global and dynamic power game. This power game takes place within an anarchical international system in which every state is dependent on providing for itself and its own security. The primary function of each actor is to maximize either its power or security accordingly and thus to achieve the most important goal - the survival of the state - in the long term. Power and security naturally play a decisive role in achieving that goal. National security at the level of states must, however, be viewed from two sides since states are both the threatened objects and the threatening subjects in international relations. This aspect of threat arises from the military capabilities of other foreign actors/states (Devetak et al. 2011, p. 162). For Realists, the world and the events taking place in it are regarded as a zero-sum game. An actors' focus is on relative gains. From the perspective of Realists, two options can therefore be proposed for reacting appropriately to threats emanating from foreign states. On the one hand, states can establish their own national armed forces for direct defense and deploy them accordingly. On the other hand, there is also the option of participating in or forming coalitions in order to be able to counter potential 
enemies in a balanced manner. In a Realist approach, alliances and partnerships are thus not the result of common ideological foundations, but rather the product of congruent specific interests of two or more actors at a given point in time. The goal of both options is to maintain the position of power and to be able to react to threats. Material forces, such as the deployment and use of armed forces, and their distribution within the international system are ultimately subject to a national cost-benefit analysis based on national interests (Devetak et al. 2011, p. 164).

During the Cold War, where security was always linked to the question of war and peace, the Realist approach dominated. Here, naval power was mostly investigated through naval studies, prepared by historians and strategists. Their focus was on naval forces as an instrument of states, and the sea as an environment was neglected. "From a Realist perspective, sea power is understood as a sum of assets, that is to say a powerful navy, an efficient merchant fleet (although today the states that possess the most powerful navies are no longer those that possess the largest merchant navies), and some invariable geographical factors which contribute to states' power" (Germond 2015, p. 7). Naval power here serves primarily to contribute to national and economic security at sea or from the sea. Maritime assets are used to maximize power through control at sea in order to satisfy national interests and to be able to pursue power politics. Thus, naval forces are traditionally considered an indicator of power and have also contributed to the reputation of states (Till 2009, p. 253). Even if quantitative indicators of navies, such as the number of ships or the performance of weapon systems, allow a ranking in which navies can be listed, from a Realist perspective, however, the relationship to other navies is more important than the absolute numbers of capabilities (Jackson 2010, p. 12). This naval balance between states has been studied by traditional naval researchers mostly on a technical, tactical, operational, or strategic level. For example, winning wars and achieving dominance at sea, including by waging decisive battles, were of central importance for classical writers such as Mahan or Corbett (Hill 1986, p. 35). Eric Grove (1990, p. 3) summarizes sea power therefore as a "form of military power that is deployed at or from the sea."

Global power equals sea power. Since Thucydides maritime powers, as a mean of maintaining the "balance of power," establish thalassocracies as agents of global power. This Realist perspective on sea power is highlighted by the arms race of naval forces before the First World War and during the Cold War. In both cases, the parties involved pursued the goal of building up powerful naval forces in order to be able to take a position of strength compared to their competitors in the event of aggression. This approach, after more and more ships and stronger weapons systems, was also pursued by Soviets during the Cold War, whereby the USA and NATO were able to maintain a favorable balance of power at sea despite great Soviet efforts. This ratio contributed to the downfall of the Soviet Union, as the economic burden of operating a navy of this size became a factor not to be underestimated. After the end of the Cold War, Realism regarding sea power was called into question due to the expansion of the concept of security. In particular, new threats such as terrorism at sea or piracy as well as new types of operations (humanitarian or peacekeeping missions) could not be explained by mere power considerations (Germond 2015, p. 8). 


\section{Liberalism and Sea Power}

Liberalism is the second school of thought that competes with Realism, emphasizing that liberal democratic states are not driven by egoism but rather force cooperation among themselves based on common goals-which go beyond mere survival. A parallel to realism is required when considering the international system. Liberalism also speaks of anarchy at the international level. However, cooperation is still possible here, since cooperation serves (economic) interests. There are thus interests that go beyond national security. Of particular importance is economic prosperity, which is achieved through market economy principles and free trade. Consequently, states should establish peaceful relations in order to create a free market and institutions/regimes that serve the spread of liberal norms and globalization on a global scale. International military cooperation should serve stability and prosperity and is thus a by-product of liberal thinking (Germond 2015, p. 8). Strachan sees a symbiotic connection between sea power and liberal democracy (2005, p. 38). This supports the argument that the development of navies and national agendas regarding the use of the oceans was favored by liberal democracies (Grygiel 2012, p. 33).

In contrast to Realism, sea power in Liberalism should be understood as something collective that drives the promotion of liberal norms and cannot be viewed solely in terms of national interests. This coincides with the aspect of the definition of maritime power already described - the possibility of shaping the behavior of others and thus also the international system. Maritime power offers the chance to spread free trade and liberalism through the control of the seas and thus to secure maritime common goods. This is also made clear in a document published by US naval authorities, which confirms that US sea power cooperates with others with the goal of creating prosperity and security (US Navy, Coast Guard, and Marine Corps 2007, p. 19). The influence and impact of sea power is emphasized and not the pure outreach of sea-going units in conflicts (Lindley-French and Straten 2008, p. 67).

As mentioned, a central component of Liberalism is free trade, which must be ensured by the freedom and security of the seas and trade routes. The naval forces serve as a means to this end within the framework of multilateral deployment. This multilateralism does not therefore represent an emergency solution - as in Realism due to a lack of naval capabilities at the national level. Examples such as the deployment of multilateral naval forces in the Strait of Hormuz or the Persian Gulf support this statement. A special feature is the cooperation of the Chinese Navy with Western partners in the Horn of Africa. This shows that cooperation between liberal and non-liberal actors takes place in order to spread the liberal world order. This cooperation also includes the implementation of foreign interventions, if this can lead to regional stability and the dissemination of liberal norms. Following this approach, it must be recognized that sea power in Liberalism also contributes to the projection of power and armed forces. This is illustrated by the use of naval forces in operations such as those in Kosovo (1999) and Libya (2011). Sea power in Liberalism thus not only represents national security but also includes as goals the stability and spread of the liberal order, which are to be implemented through a variety of mission scenarios (combat operations, maritime diplomacy, combating piracy, 
deterrence, etc.) (Germond 2015, p. 9). The school of Liberalism has been particularly present since the end of the Cold War but features of liberal principles relating to naval power can be found much earlier. Themistocles, Thucydides, and Xenophon (as well as Mahan) described the sea as a collective good. The freedom of the seas is essential for economic development and the prosperity of states (O'Tuathail 1996, p. 39). Oceans and sea power have been favoring globalization, which is why sea power is always accompanied by geo-economic goals (Tangredi 2002, p. 22). Liberalism has experienced a particular upswing since the end of the Cold War, however, because of the assertion of Western liberal values. Looking at current deployment scenarios, cooperation among naval forces is the norm at the international level.

China's rapid rise and the associated power-political aspirations of China have led to a revival of the view of sea power through Realism. The decisive factor in challenging the liberal approach is China's goal of having a navy capable of serving national interests. Since China is dependent on trade and, in terms of its energy security, also on the use of the oceans, China no longer sees itself solely as a land power but also as a growing sea power (Xiaoqin 2012, p. 75). Actions such as the launch of the first Chinese aircraft carrier have the potential to provide greater competition at the maritime geopolitical level. A potential maritime arms race with competitors such as India or even a potential clash with the USA, for example, through the conflict over Taiwan, reasserts a Realism inspired perspective on these areas of conflict (Brzezinski and Mearsheimer 2005). However, there also is cooperation between the USA and China. China's participation in the anti-piracy mission, for example, has shown that cooperation and some form of collaboration is possible.

\section{Origins of Sea Power}

This chapter presents the origins of the concept of sea power, which was significantly influenced by Mahan and Corbett. Both are the leading naval thinkers of the socalled blue-water school. Mahan, "the father of modern naval history" (Moll 1963, p. 132), pursued a historical approach to the analysis of sea power in order to create universally applicable rules, rather than a theoretical one. Corbett was primarily concerned with the effectiveness of sea power during conflicts.

\section{Mahan's Principles of Sea Power}

In reference to land warfare, Mahan emphasized three principles that are of crucial importance: first, he stressed the inherent value of a strategic central position, emphasized the principle of concentration, and saw a crucial relationship between logistics and combat (Crowl 1986, p. 456). For Mahan, the strategic value of a place is defined by the position/situation, the military strength (offensive/defensive), and the resources available at the place. He concludes that taking a place of great strength may not be worthwhile due to weaknesses in its strategic lines or lack of resources. 
As mentioned, Mahan emphasizes the inherent value of a central position, but not in its absoluteness. He sees the central position as a supporting element that exists alongside many other supporting elements. Thus, the benefit of a central position is very limited when there is a stronger enemy on both sides (Mahan 1911, p. 32). So, such "a position does not give also the most men needed to complete the familiar aphorism. The position in itself gives no large numbers, and when left it serves only the defensive purpose of a refuge, a base of supplies, lines of communications. A central position cannot be carried to the field or as reinforcement" (Mahan 1911, p. $55)$.

According to Mahan, victory at sea is only possible through an appropriate fleet concentration, which is accompanied by the fact that the fleet is never divided (Gough 1988, p. 56). According to Mahan, this concentration of fleets is the most important instrument of naval warfare. Concentrated fire on the enemy fleet should be the main means of the battle fleet to exercise sea power (Crowl 1986, p. 458). Under this central principle of concentration, Mahan summarized all strategic and tactical considerations for achieving military efficiency in war, ignoring intermediate operational levels in keeping with the spirit of the times (Vego 2009, p. 2).

The third principle, the connection between logistics and combat, was of central importance to Mahan due to the technological events of his time. Naval bases were indispensable because ships powered by steam were not able to cover a considerable distance without stopping. The logistic supply by far-away coaling stations became a necessity in order to be able to sail and operate beyond home waters in times of war. A successful maritime strategy was not possible without these logistics (Crowl 1986, p. 460). This is accompanied by the supply lines that Mahan called the most important strategic lines. He defined them "as a line of movement through which a military body is kept in living communication with the national power" (Mahan 1913, p. 33). These are not geographical lines but lines that must be followed to transport supplies (fuel, ammunition, and food) to the naval fleet (Mahan 1913, p. 33).

Beyond these three principles, there are other essential points. For Mahan, the separation between the navy, an element that always had to be deployed strategically/tactically offensively, and the coast guard, a defensive factor, was very important (Mahan 1913, p. 458). This separation was based on the consideration that the defense of ports would limit the offensive power of the fleet. Furthermore, he sees this distinction supported by the fact that the fleet should maintain its mobility, while defense is always characterized by immobility (Alfred T. Mahan 1911, p. 459). Furthermore, there were two main methods for him to gain and maintain command over the sea: the decisive battle and the blockade. The main task of the fleet was to attack the enemy fleet in order to destroy the enemy and gain control over the water. This could only be achieved by a decisive and clear victory in the form of a decisive bad. These considerations led to the fact that during the First World War many navies neglected operational warfare but relied on tactics and technology to win the decisive battles (Vego 2009, p. 3).

A tight blockade can still lead to the detention of merchant and even naval ships in their own ports. He was aware, unlike many of his contemporaries, that the 
development of submarines would make tight blockades more difficult, so a greater distance between the blocking ships and the blocked ports had to be taken. However, this long-distance blockade would be made possible by an increased demand for ships, so technical progress does not change the basic principle of the blockade (Mahan 1913, p. 3).

In retrospective, Mahan's elaborations were adopted relatively uncritically and were followed dogmatically. The reliance on the superiority of large ships (so-called capital ships) in major naval battles was used as a basis for the construction of navies. Mahan's indications that convoy, for example, was an effective method of protecting shipping were practically ignored for a long time (Bowling 1980, p. 2).

Mahan's ideas about the importance of the battle fleet and the decisive battle were uncritically adopted by his interpreters. This blind acceptance had the consequence that the great navies of those days gave priority to capital ships. The number and technology of the dreadnought class ships was defined as a decisive factor for future conflicts in order to achieve command at sea by winning a decisive naval battle. This link between naval battle and command of the seas had been established by Mahan in historical studies covering the period between 1660 and 1783 and was widely accepted. The strategic dimensions of the early twentieth century and the extent of a worldwide industrially based war were not recognized (Kutz 1989, p. 8).

Mahan's principles were applied during the First World War. Especially the Germans were convinced of the concept of the great decisive battle, although Mahan had never considered other possibilities of naval warfare such as cruiser wars or amphibious landings as useless. Options such as attacking British naval trade to weaken the enemy or preventing the landing of British troops in France did not receive adequate attention. The central problem of the Germans was that they did not pay sufficient attention to the value of the maritime position for a successful deployment on the open sea. Thus, German ships were prevented by the Allies from reaching the open waters of the Atlantic. With the stopping of German deep-sea traffic, the fleet was no longer able to prevent a British sea blockade (Vego 2009, p. 5).

Even after the First World War, the US Navy concentrated on building a strong combat fleet. The majority of the naval leadership was focused on material and it was assumed that smaller ships such as destroyers could be produced relatively quickly in case of emergency. Tactically, too, the emphasis continued to be placed on major decisive battles, as they were preparing for the same ones with the Japanese in the Pacific. The Japanese side followed similar views, and many Japanese admirals were also followers of Mahan. Aircraft carriers and submarines were regarded as auxiliary forces for the capital ships that formed the core of the navy. On the Japanese side, there was only a small group of admirals who believed in the aircraft carrier as the ship of the future. This group was not influential enough to achieve changes in naval doctrine until the beginning of the Pacific War in 1941 (Bowling 1980, p. 308). 


\section{Sir Julian Corbett and Sea Power}

Corbett, a lawyer and writer and thus the only civilian in the ranks of blue-water naval thinkers, sees the navy and its strategic deployment as an integral part of the art of war. With Clausewitz' concept in mind, he sees the strategic and tactical deployment of fleets not as an end in itself but to achieve corresponding goals in war and thus political ends (Gough 1988, p. 58). He was the first theoretician to deal with a strategy for an inferior sea power in conflict with a continental power. Further, he was a thought leader on the direct contribution that maritime strategy can make to a war on land (Vego 2009, p. 6).

Corbett divided maritime strategy into two types: first, the major strategy that dealt with the purpose of war. This also included a consideration of international relations and economic functions. The second was the minor strategy, which dealt with the actual aspects of warfare. Here, the planning and conduct of army and navy operations (and also combined operations) are considered (Gough 1988, p. 58). Corbett made a further distinction between maritime and naval strategy. The maritime strategy plays a superior role in the sense of planning the mutual relations between army and navy within a war plan. Only on this basis can a naval strategy, that is operational warfare at sea, be planned in order to deploy the fleet in the best possible way for the missions defined in the maritime strategy. Corbett was aware that a war cannot be decided by winning naval battles alone, as this would only involve a long process of exhaustion of the enemy (Corbett 1918, p. 12).

Central to Corbett was the goal of naval warfare: to gain and maintain command at sea while preventing the enemy from gaining it (Grove 1990, p. 12). Corbett equated command with the control and maintenance of commercial and military lines of operation, communication, and supply. "Thus, to keep open 'lines of operation' and 'lines of communication' offered the strategic objective for which the navy would function. Supply lines, running from bases to theatres of operations, lateral lines linking theatres, and lines of retreat, that is, supply lines in reserve these were the avenues of war" (Gough 1988, p. 59).

According to Corbett, maritime operations cannot be viewed in the same way as the rest of military operations. The fundamental difference is that in land warfare, an attempt is made to take over the enemy's territory, while in sea warfare the focus is on the control of "communication," that is the control lines of operation, communication, and supply. Outside the territorial waters, the sea is not owned by anyone, so maritime communication is the same for both warring parties. This means that offensive and defensive planning of operations must take place at the same time, since it is usually impossible to attack an enemy without defending oneself. The sea is still not capturable to the same extent as on land, because it is not possible to keep the troops at sea as it is possible on land. And even if there is local control, the fleet is ultimately forced to find and fight the enemy fleet (Corbett 1918, pp. 78-80).

Similar to Mahan, for Corbett, obtaining command of the sea, that is, control of the aforementioned communications, was possible through battles and a blockade (or both). The sense behind all these measures always depends on the political conditions that make this control of the sea possible. For this purpose, not only 
offensive but also defensive measures such as the protection of civil shipping could be used (Vego 2009, p. 7). At the same time, according to Corbett, the command over the sea can be threatened by hostile, smaller tactical actions or even the deployment of the enemy fleet. The defense against the invasion of the enemy, the attack on the enemy, and the defense of one's own maritime trade as well as the support of one's own military expeditions are the decisive factors for the exercise of a maritime command (Corbett 1918, p. 149). It can be clearly seen that Corbett mixes the offensive and defensive tasks of the navy in the exercise of the naval command. Corbett also sees in this context task fields such as the attack and defense of naval trade, which must be carried out continuously for the entire duration of a war by both parties, including the weaker sea power. The example of the defense of one's own shipping clearly illustrates this mixture, since the actual defensive task also has an offensive character; the attack and destruction of the enemy fleet always leads to a better protection of one's own shipping (Vego 2009, p. 7).

Corbett did not see the classic occupation of territories in terms of command at sea. He defined the power of command with freedom of movement of one's own fleet without hindrance or resistance, while at the same time restricting the enemy in his freedom of movement. However, in his view, the most common condition at sea is that neither side is in command. If one side should lose command, this does not automatically transfer to the other side (Grove 1990, p. 12). In other words, this means that a war between two opponents at sea is a battle for the power of command, which is usually controversial. In order to change this state of affairs, sea strategists deal with measures for the fleet to gain command. Should one side win command, the pure sea strategy is over for the other side that has lost (Corbett 1918, p. 77).

Compared to Mahan, Corbett looked at the actual leadership at sea in much more detail. Command of the sea had to be considered in various states and forms in order to enable the development of a war plan accordingly. In doing so, he differentiated the command at sea, both spatially (general and local) and temporarily (permanent and temporary). A general command can be permanent or temporary, while a local command, on the other hand, can only be considered temporary, since the enemy should always be able to interrupt the deployment of his fleet from other locations. He even goes so far as to say that no degree of superiority protects against sporadic attacks by detached cruisers or raiding squadrons, provided that they are prepared to take a correspondingly high risk and risk their own destruction (Corbett 1918, p. 90).

According to Corbett, a decision must be obtained to gain control of the sea. However, unlike Mahan, he did not always consider a decisive battle to be necessary. Corbett wrote in this respect that "under certain conditions, therefore, it may not be the primary function of the fleet to seek out the enemy's fleet and destroy it, because general command may be in dispute, while local command may be with us, and political or military considerations may demand for us an operation for which such local command is sufficient, and which cannot be delayed until we have obtained a complete decision" (Corbett 1918, p. 214).

Contrary to Mahan, Corbett held the view that fleet concentration need not be a fixed element, but that wars at sea are fought through strategic combinations and decisions that require a degree of flexibility and freedom of movement. Victory can 
only be won by prudent use of the greatest risk, that is, the division of the fleet. This flexible approach ensures that one can hide one's own intentions from the enemy for as long as possible and allows the Navy to adapt to the previously drawn up operational plan (Corbett 1918, p. 115). Without a division, flexible operations on a strategic level are not possible on a dynamic battlefield like the sea. As mentioned above, this approach involves risks (as well as factors such as the enemy's resources or even the weather, on which one has no direct influence), but these risks are necessary to achieve success. If you follow the approach of concentration, the enemy is much clearer about what the further intention is, and you deprive yourself of flexibility. Corbett wrote: "the further from the formation of the ultimate mass we can stop the process of concentration, the better designed it will be" (Corbett 1918, p. 120).

\section{Changes After the Second World War}

Already during the Second World War, new considerations began to be verbalized on a tactical and strategic level. As early as 1943, the first ideas of a common military culture within a holistic framework were being considered, so that a grand strategy for achieving victory could be developed by using all available means (Mortensen 1987, p. 15). In concrete terms, the Second World War ended the era of the great battleships, which of course also had strategic and tactical implications and further developed the complexity of joint operations, that is, uniting all branches of the armed forces (Torres 2013, p. 718).

The beginning of the Cold War marked a security environment that was considered the basis for naval planning and was characterized by a bipolar structure of two different political systems and alliances (NATO and the Warsaw Pact) (Smith and Uttley 1999, p. 1). The technological advances that came with the times, such as the nuclear revolution and the development of supersonic aircraft, made naval theorists increasingly abandon Mahan's views and focus more on Corbett's maritime strategy, that is, the interplay between air, land, and naval forces (Heuser 2010, p. 275). This was followed by a further development of the concept of command at sea toward a strategy of naval control, which had the goal of "connote more realistic control in limited areas and for limited periods of time (...)" (Heuser 2010, p. 274).

In the interwar period, the usefulness of a strong navy was questioned because of its vulnerability to air attacks. Furthermore, it became clear that the danger of nuclear aggression was too great for a naval ship, so the navy was superfluous. Admiral Sir Herbert Richmond countered the first argument as early as 1934 by arguing that airplanes are also corresponding instruments of a naval power, since they embody weapons that can be used in such a way that they enable control of the sea. Furthermore, he considered the danger from air to be less than from enemy ships. In addition, he justified the necessity of the navy by stating that a fleet that could be deployed in a certain area for a longer period of time and with greater effectiveness in virtually any weather outperforming the capabilities of aircrafts (Richmond 1934, p. 117). 
Regarding the second argument of the nuclear threat, it can be stated that with the technological development of nuclear-powered submarines, which are also equipped with nuclear missiles, sea power has been given a role in a possible nuclear war (Heuser 2010, p. 293). It is fair to say, however, that in such a doomsday scenario the remaining naval forces (and many air and land forces as well) could only take on the role of auxiliary and rescue forces (Gretton 1965, p. 97). Because of this increasingly dangerous scenario, which of course resulted from the bipolarity of that time, a new concept of sea control was developed at the strategic level, which should be able to provide deterrence (by punishment or denial) against a nuclear attack (Till 2009, p. 292). Despite this concept, the vulnerability of naval forces to, for example, missile attacks, remained, so a key question was how well naval forces could adapt to (technical) changes during their lifetime (Friedman 2001, p. 244).

Within the concept of sea control, the naval forces take on different roles. Naval forces have three main functions - military, diplomatic and police - with which the navy fulfills its purpose. Of course, the military function is in the foreground, since the naval forces are accordingly geared to perform tasks such as strategic deterrence and thus power projection, coastal defense or the defense of civilian shipping (Grove 1990 , p. 233). The role of diplomacy is not new and has occurred again and again historically, since diplomatic relations have usually always been linked to the line of communications between countries. Joint exercises or supporting partners within the alliances are examples of how naval diplomacy is applied. The third function, the police function, can also be compared to a constitutional role, since "the navy can maintain national sovereignty, protect national resources and, of course, preserve international peacekeeping" (Torres 2013, p. 720).

The adaptability and the ability to perform several of the tasks practically simultaneously set the naval forces apart from the rest of the partial armed forces. The various roles can be changed within a short period of time in order to be able to react flexibly in line with the strategy and adapted to the situation. A further advantage of naval forces is their ability to move freely in the world's oceans; the only restrictions are of a geographical nature or the territorial waters of the respective countries. Otherwise, naval forces can move freely and without local permission. This is not the case with, for example, ground-based air forces and armies, since they need either negotiations, allied territory, or the seizure of operational areas in order to be able to act accordingly (Friedman 2006, p. 41). A further advantage of naval forces is, as Richmond (1934, p. 117) has already correctly recognized, that naval forces can maintain a presence for a long time and are thus able to carry out patrols for much longer than air forces alone. Naval forces are also technologically superior to air forces in terms of transporting large units and equipment in large quantities to the area of operations (Torres 2013, p. 720).

In order to do justice to all these roles and also to organize the cooperation between the individual branches of the armed forces, as already discussed by Corbett, the naval forces (like the other branches) are subject to continuous technological progress. With their beginnings in the Second World War as support units, aircraft carriers or carrier battle groups today represent the technological pinnacle of how multi-role naval forces can be operated. More than almost any other unit of 
armed forces, carrier battle groups combine strong offensive and defensive capabilities (Friedman 2001, p. 256). Aircraft carriers enable joint operations across the various branches of the armed forces and combine sea control with air superiority. This combination makes it possible to provide effective support for amphibious troop formations while at the same time maintaining a large tactical range. The composition of the carrier battle groups ensures a high degree of security against enemy attacks. Today's aircraft carriers are so far advanced in their technological development that they practically act as a mobile base (and airport) and are thus considered sovereign, mobile territory (Friedman 2006, p. 42).

\section{Different Levels of Maritime Engagement}

In order to give the supposedly abstract concept of Sea Power an even more practical reference, the levels of today's maritime operations will be briefly discussed below. For Corbett, the strategy also included the operations of a naval campaign. The American Admiral J.C. Wylie put it this way: tactics are in effect when there is contact between one's own and enemy forces, which is why all plans and operations are tactical. Everything else is strategic (Hughes 2012, p. 24). Today, however, there is a corresponding division of levels - strategic, operational, tactical - in maritime operations. The highest level is the strategic level, where nations (often embedded in multinational alliances such as NATO) define national and multinational objectives, guidelines, and the appropriate use of military and other instruments.

This is followed by the operational level, which has the purpose of combining national or military strategic objectives with the corresponding tactical deployment of the armed forces, including the naval forces. It is at this level that operations are planned and carried out to achieve objectives within theatres of war and also in other areas of operation. This implies a larger time and space frame than at the tactical level, since it is here that the corresponding intermediate operational steps to achieve the strategic goals defined.

The level of battles and combats, that is, the deployment of, for example, naval forces, forms the tactical level for achieving military objectives defined by the operational command. Here it is primarily about the orderly formation and maneuvering of the corresponding units in order to achieve combat objectives against the enemy. The tactical objectives form the individual steps toward the operational objective, with the totality of the operational objectives forming the strategic objectives.

Despite this definition of the different levels, the transitions between the levels of a war are fluid, as units or, for example, types of equipment do not have to be assigned to a specific level. One example of this is reconnaissance and communications satellites, which used to be deployed exclusively at the strategic level, but which today also represent a crucial component of tactical operations. 
Naval forces and naval bases can also be deployed at all three levels to achieve strategic, operational, or tactical objectives. One example: In the Second World War, a war in its entirety on a strategic level, battles were fought on an operational level, for example in the Pacific region, which in turn were fought on a tactical level by naval forces (and also air and land forces) in the corresponding battles on the ground. The victories at the tactical level in the many battles fought by, for example, naval forces enabled an overall victory in the Pacific region, which in turn was decisive for the strategic victory of the Allies (US Navy 2010, pp. 17-18).

\section{Summary}

Finally, it remains to be said that the concept of sea power has been subject to change and constant further development over the decades. The historical significance of sea power was mentioned at the beginning of this chapter, and its relevance during the twentieth century was sufficiently demonstrated. Sea power will not lose relevance in the twenty-first century as the concept shows its relevance for International Relations when viewed from different perspectives (such as Realism or Liberalism). It can rather be assumed that the value of sea power will increase to the same extent as the world trade with the means of transportation by ships will grow in the center of the world trade system. This will inevitably have an impact on the role and significance of naval forces. It can be said with certainty that - regardless of the individual task, be it support for police tasks or defense of one's own waters - the naval forces and the concept of sea power will continue to develop and become increasingly important.

\section{References}

Bowling, A. R. (1980). The negative influence of Mahan on the protection of shipping in wartime: The convoy controversy in the twentieth century. Maine: University of Maine.

Brzezinski, Z., \& Mearsheimer, J. (2005). Debate: Clash of the titans. Foreign Policy, 146, 46-50. Corbett, J. S. (1918). Some principles of maritime strategy. London: Longmans, Green.

Crowl, P. A. (1986). Alfred Thayer Mahan: The naval historian. In P. Paret (Ed.), Makers of modern strategy. From Machiavelli to the nuclear age (pp. 444-480). Princeton, NJ: Princeton University Press.

Devetak, R., Burke, A., \& George, J. (Eds.). (2011). An introduction to international relations (2nd ed.). Cambridge: Cambridge University Press.

Friedman, N. (2001). Seapower as strategy. Annapolis: Naval Institute Press.

Friedman, N. (2006). The carrier: A US view. RUSI Defence Systems, 9(1).

Germond, B. (2015). Seapower and international relations. In B. Germond (Ed.), The maritime dimension of European security: Seapower and the European Union (Palgrave studies in European Union politics) (pp. 5-17). London: Palgrave. 
Gough, Professor Barry M. (1988). Maritime strategy: The legacies of Mahan and Corbett as philosophers of sea power. The RUSI Journal, 133(4), 55-62.

Gray, C. S. (1999). Modern strategy. New York: Oxford University Press.

Gretton, P. (1965). Maritime strategy. London: Cassel \& Company.

Grove, E. (1990). Future of sea power. Annapolis: Naval Institute Press.

Grygiel, J. (2012). Geography and Seapower. In P. Dutton, R. Ross, \& Ø. Tunsjø (Eds.), Twenty-first century seapower : Cooperation and conflict at sea (pp. 18-41). New York: Routledge.

Heuser, B. (2010). The evolution of strategy. Cambridge: Cambridge University Press.

Hill, J. R. (1986). Maritime strategy for medium powers (1st ed.). Annapolis: Naval Institute Press.

Hughes, W. P. (2012). Naval operations. Naval War College Review, 65(3), 23-47.

Jackson, A. P. (2010). Keystone doctrine development in five commonwealth navies: A comparative perspective. Papers in Australian Maritime Affairs, 33, 81.

Kutz, M. (1989). Operative Führung Als Denkfigur Und Handlungskonzept Der Heeresführung Der Bundeswehr. Politische Und Militärfachliche Implikationen Und Gefahren Der Aktuellen Diskssion (Beiträge Zu Lehre Und Forschung). Hamburg: Führungsakademie der Bundeswehr, Fachgruppe Sozialwissenschaften.

Lindley-French, J., \& van Straten, W. (2008). Exploiting the value of small navies: The experience of the Royal Netherlands Navy. The RUSI Journal, 153(6), 66-69.

Mahan, A. T. (1911). Naval strategy compared and contrasted with the principles of military operations on land. Boston: Little, Brown.

Mahan, A. T. (1913). The major operations of the navies in the war of American independence. Boston: Little, Brown.

Moll, K. L. (1963). A.T. Mahan: American historian. Military Affairs, 27(3), 131-140.

Moore, J. (1975). The constancy of sea power in strategic considerations. International Perspectives, $13-18$.

Mortensen, D. R. (1987). A pattern for joint operations: World War II close air support, North Africa. Washington, DC: Office of Air Force History and U.S. Army Center of Military History.

Nailor, P., \& Bolton, D. (1986). The utility of maritime power: Today and tomorrow. The RUSI Journal, 131(3), 15-21.

O'Tuathail, G. (1996). Critical geopolitics (1st ed.). Minneapolis: University of Minnesota Press.

Richmond, H. (1934). Sea power in the modern world. Cambridge: Cambridge University Press.

Sater, W. F. (1991). The rise and fall of the Chilean Navy 1879-1905. In New interpretations in naval history. Annapolis: Naval Institute Press.

Smith, M. L., \& Uttley, M. R. H. (1999). Tradition and innovation in maritime thinking. In A. Dorman, M. L. Smith, \& M. R. H. Uttley (Eds.), The changing face of maritime power (pp. 113). London: Macmillan.

Strachan, H. (2005). The lost meaning of strategy. Survival, 47(3), 33-54.

Tangredi, S. J. (2002). Globalization and sea power: Overview and context. In Globalization and maritime power (Institute for national strategic studies) (pp. 1-24). Washington, DC: NDU Press.

Till, G. (1984). Maritime strategy and the nuclear age (2nd ed.). London: Palgrave Macmillan.

Till, G. (2009). Seapower: A guide for the twenty-first century (2nd ed.). Abingdon: Routledge.

Torres, M. (2013). Revisiting the naval power: Are navies redundant in an age of aircraft and missiles? Revista Militar, 2539, 715-724.

US Navy. (2010). Naval warfare. Naval Doctrine Publication 1, United States Government.

US Navy, Coast Guard, and Marine Corps. (2007). A cooperative strategy for 21st century seapower.

Vego, M. (2009). Naval classical thinkers and operational art. The United States Naval War College.

Xiaoqin, S. (2012). The boundaries and directions of China's seapower. In P. Dutton, R. Ross, \& Ø. Tunsjø (Eds.), Twenty-first century seapower: Cooperation and conflict at sea (pp. 65-84). New York: Routledge. 
Open Access This chapter is licensed under the terms of the Creative Commons Attribution 4.0 International License (http://creativecommons.org/licenses/by/4.0/), which permits use, sharing, adaptation, distribution and reproduction in any medium or format, as long as you give appropriate credit to the original author(s) and the source, provide a link to the Creative Commons license and indicate if changes were made.

The images or other third party material in this chapter are included in the chapter's Creative Commons license, unless indicated otherwise in a credit line to the material. If material is not included in the chapter's Creative Commons license and your intended use is not permitted by statutory regulation or exceeds the permitted use, you will need to obtain permission directly from the copyright holder.

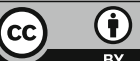

